3. Scheich, H. et al. Eur. J. Neurosci. 10, 803-809 (1998). 4. Woldorff, M. G. et al. Hum. Brain Map. 7, 49-66 (1999). 5. Griffiths, T. D. et al. Nature Neurosci. 1, 74-79 (1998).

6. Awh, E. \& Jonides, J. in The Attentive Brain (ed. Parasuraman, R.) 353-381 (MIT Press, Cambridge, MA, 1998).

7. Galaburda, A. M., Le May, M., Kemper, T. L. \& Geschwind, N. Science 199, 852-856 (1978).

8. Belin, P. et al. J. Cogn. Neurosci. 10, 536-540 (1998)

9. King, A. J. \& Hutchings, M. E. J. Neurophysiol. 57, 596-624 (1987).

10. Ahissar, M., Ahissar, E., Bergman, H. \& Vaadia, E. J. Neurophysiol. 67, 203-215 (1992).

\section{Striped rabbits in Southeast Asia}

The Annamite mountains of Laos and Vietnam have yielded several important mammalian discoveries ${ }^{1}$. We have found a striped rabbit of the previously monospecific genus Nesolagus, extending its known range more than $1,500 \mathrm{~km}$ north from the island of Sumatra into mainland Southeast Asia. The Sumatran and mainland Annamite populations are morphologically similar, but genetic data indicate that they have been isolated for millions of years.

The first evidence of Nesolagus in the Annamite mountains came from freshly captured animals offered for sale in a food market in the rural town of Ban Lak, Laos $\left(18^{\circ} 11^{\prime} \mathrm{N}, 104^{\circ} 58^{\prime} \mathrm{E}\right)$ between December 1995 and February 1996 (Fig. 1). The rabbits have since been found at other sites in the Annamite mountains of Vietnam.

The only previously known striped lagomorph was the critically endangered Nesolagus netscheri, a monotypic rabbit genus endemic to forest habitat within the Barisan

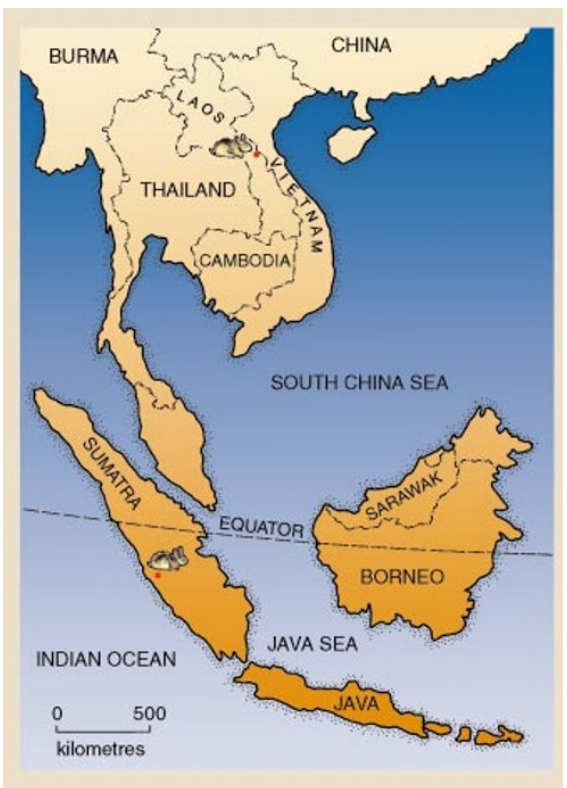

Figure 1 Map of Southeast Asia showing the Sunda islands of Sumatra, Borneo and Java. The site of the first discovery of a striped rabbit in the Annamites of central Laos is marked, as is the Kerinci Seblat National Park in Sumatra, where Nesolagus netscheri was photographed in the wild. mountains and further north to Mount Leuser in Sumatra. There had been just one confirmed sighting of $N$. netscheri since 1916 and only around 15 museum specimens of the species exist, all of which were collected between 1880 and 1929 (ref. 2). In early 1998, N. netscheri was photographed by an automatic camera trap in the Kerinci Seblat National Park in Sumatra by Fauna and Flora International ${ }^{3}$. Externally, the Annamite rabbits closely resemble $N$. netscheri, having black or dark brown dorsal stripes, ferruginous rumps and short tails and ears (Fig. 2).

Morphological analysis of 30 characters (including pelage elements, external proportions, postcranial characters, tooth morphology and cranial morphometrics) in both Annamite and Sumatran rabbits reveals that there is a significant difference in the minimum interorbital distance as a percentage of condylobasal length (Annamite, range 19.0-23.6, mean $( \pm$ s.d. $)$ 20.5 ( \pm 1.6$), n=10$; Sumatran, 16.9-18.7, $17.5( \pm 0.7), \quad n=6 ; \quad P<0.001$, WilcoxonMann-Whitney test).

Genetic analysis was undertaken of 653 continuous base pairs of the mitochondrial gene encoding $12 \mathrm{~S}$ ribosomal RNA prepared from three museum specimens of $N$. netscheri and three rabbits from Laos. The results indicate that $N$. netscheri and the Annamite specimens (Genbank accession numbers AF176583 to AF176589) are sister taxa within a phylogenetic framework of lagomorph genera ${ }^{4}$. There is considerable divergence between them: the genetic distance (Kimura two-parameter) is 0.0552 , which falls outside the range observed between other congeneric leporid species (0.0226-0.0427, mean 0.0324, from six species in two genera), but within that between different leporid genera (0.0469-0.1199, mean 0.0748, from seven genera). Assuming a steady rate of divergence over time at this gene $e^{5}$, the Sumatran and Annamite rabbits would have been diverging genetically for approximately 8 million years.

Despite an apparently high degree of conserved morphology, the large genetic divergence between these two taxa of striped rabbit indicates that they separated in the Pliocene epoch. In this region, glacial periods were cool and dry, characterized by expanding grassland, whereas forest cover increased during interglacial periods ${ }^{6}$. During glacial maxima, sea levels over the Sunda shelf were almost 150 metres lower than today, connecting Sumatra, Java and Borneo to the Asian mainland ${ }^{7}$. The ancestral Nesolagus may have been distributed over areas of this region at a time of lower sea level in the Pliocene, and its range would have been repeatedly dissected by periodic changes in both sea level and forest habitat.

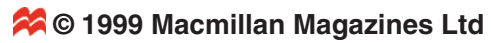
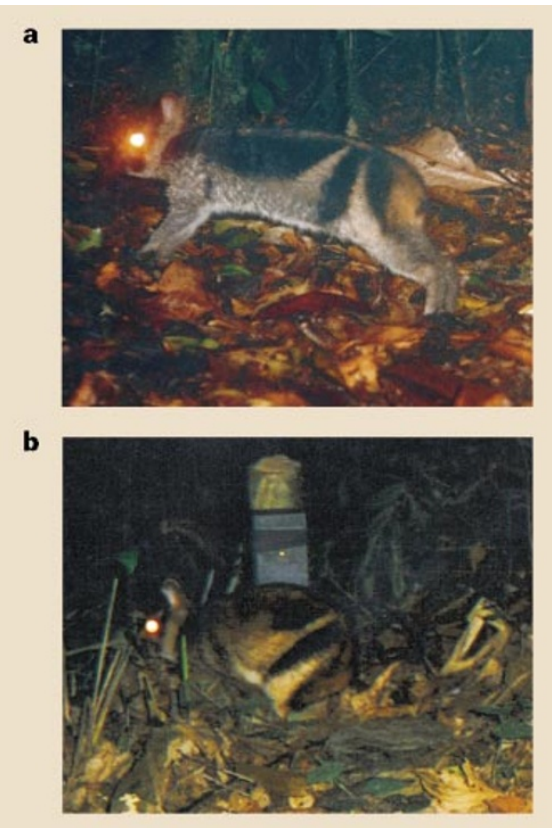

Figure 2 Automatic camera-trap photographs of the striped rabbits. a, Nesolagus netscheri in Kerinci Seblat National Park in Sumatra (photograph from $\mathrm{FFI})$. b, The striped rabbit from the Annamite mountains, photographed in the Pu Mat Nature Reserve, Vietnam (photograph from SFNC EC).

The existence of refugia for forest species during dry glacial periods has been postulated for both the Annamite mountains and Sumatra ${ }^{8}$. The contraction and expansion of ranges in and out of such allopatric refugia can generate divergence, with the sister genomes being protected by hybrid zones if they make contact, leading to speciation? ${ }^{9}$. Our discovery of the rabbit in the Annamite mountains may provide insight into the factors governing current patterns of biodiversity in Southeast Asia, leading to its protection into the future.

Alison K. Surridge ${ }^{\star}$, Robert J. Timmins $† \ddagger$, Godfrey M. Hewitt*, Diana J. Bell ${ }^{\star}$

${ }^{*}$ Population and Conservation Biology Sector, School of Biological Sciences,

University of East Anglia,

Norwich NR4 7TJ, UK

e-mail:a.surridge@uea.ac.uk

$\dagger$ Wildlife Conservation Society,

PO Box 6712, Vientiane, Laos

$\$$ Present address: 25 Cradley Road, Cradley Heath, West Midlands B64 6AG, UK

1. Giao, P. M. et al. Anim. Conserv. 1, 61-68 (1998).

2. Flux, J. E. C. in Rabbits, Hares and Pikas (eds Chapman, J. A. \& Flux, J. E. C.) 137-139 (IUCN, Gland, Switzerland, 1990).

3. Fauna and Flora International Fauna Flora News 9, 3 (1998).

4. Halanych, K. \& Robinson, T. J. J. Mol. Evol. 48, 369-379 (1999).

5. Allard, M. W. \& Honeycutt R. L. Mol. Biol. Evol. 9, 27-40 (1992).

6. van der Kaars, W. Palaeogeogr. Palaeoclimatol. Palaeoecol. 85, 239-302 (1991)

7. Verstappen, H. T. in Modern Quaternary Research in Southeast Asia (eds Bartsra, G.-J. \& Casparie, W. A.) 3-35 (Balkema, Rotterdam, 1975).

8. Brandon-Jones, D. Biol. J. Linn. Soc. 59, 327-350 (1996)

9. Hewitt, G. M. Biol. J. Linn. Soc. 58, 247-278 (1996).

NATURE | VOL 400 | 19 AUGUST 1999 |www.nature.com 